NBER WORKING PAPER SERIES

\title{
ENGINEERING INFORMAL INSTITUTIONS: LONG-RUN IMPACTS OF ALTERNATIVE DISPUTE RESOLUTION ON VIOLENCE AND PROPERTY RIGHTS IN LIBERIA
}

\author{
Alexandra C. Hartman \\ Robert A. Blair \\ Christopher Blattman \\ Working Paper 24482 \\ http://www.nber.org/papers/w24482
NATIONAL BUREAU OF ECONOMIC RESEARCH
1050 Massachusetts Avenue
Cambridge, MA 02138
April 2018

The United Nations High Commission for Refugees (UNHCR) and the Liberian Justice and Peace Commission (JPC) implemented the intervention, and we thank Mamadou Balde, James Ballah, John Lucky, Thomas Mawolo, and Tomoko Semmyo for cooperation. Research funding came from the United Nations Peacebuilding Fund in Liberia, Humanity United, Yale University, and the World Bank's Italian Children and Youth Trust Fund. We thank Jonathan Andrews, Wilfred Grey-Johnson, Jason Hepps, Mattias Lundberg, Michael Kleinman, and Chiara Tufarelli for this financial support. For comments we thank Donald Green, Elizabeth Levy-Paluck, Suresh Naidu, and numerous seminar participants. Finally, Peter Deffebach, Mathilde Emeriau, Tricia Gonwa, Rebecca Littman, Benjamin Morse, Johnny Ndebe, Patryk Perkowski, Bryan Plummer, Gwendolyn Taylor, Prince Williams, and John Zayzay provided superb research assistance. Field research was coordinated by Innovations for Poverty Action (IPA). The views expressed herein are those of the authors and do not necessarily reflect the views of the National Bureau of Economic Research.

NBER working papers are circulated for discussion and comment purposes. They have not been peer-reviewed or been subject to the review by the NBER Board of Directors that accompanies official NBER publications.

(C) 2018 by Alexandra C. Hartman, Robert A. Blair, and Christopher Blattman. All rights reserved. Short sections of text, not to exceed two paragraphs, may be quoted without explicit permission provided that full credit, including $\left({ }^{\circ}\right.$ notice, is given to the source. 
Engineering Informal Institutions: Long-run Impacts of Alternative Dispute Resolution on Violence and Property Rights in Liberia

Alexandra C. Hartman, Robert A. Blair, and Christopher Blattman

NBER Working Paper No. 24482

April 2018

JEL No. D74,O17,P48,Q15

\section{ABSTRACT}

Informal institutions govern property rights and disputes when formal systems are weak. Wellfunctioning institutions should help people reach and maintain bargains, minimizing violence. Can outside organizations engineer improvements and reduce violent conflicts? Will this improve property rights and investment? We experimentally evaluate a UN and civil society mass education campaign to promote alternative dispute resolution (ADR) practices and norms in rural communities, where violent land disputes are common. Prior work showed a fall in violence and unresolved disputes within one year. We return after three years to test for sustained impacts and channels. Treated communities report large, sustained falls in violent disputes and a slight shift towards nonviolent norms. Treated residents also report larger farms, though overall effects on property rights and investments are mixed. Politically-connected residents report more secure property rights while those with fewer connections feel less secure. Sustained social engineering is feasible but politics shapes distributional outcomes.

\author{
Alexandra C. Hartman \\ University College London \\ 30 Tavistock Square \\ Kings Cross, London \\ United Kingdom \\ alexandra.hartman@ucl.ac.uk \\ Robert A. Blair \\ Brown University \\ Department of Political Science \\ Watson Institute for International \\ and Public Affairs \\ Providence, RI 02912 \\ robert_blair@brown.edu
}

\author{
Christopher Blattman \\ Harris School of Public Policy \\ The University of Chicago \\ 1155 E 60th St. \\ Chicago, IL 60637 \\ and NBER \\ blattman@uchicago.edu
}




\section{Introduction}

Informal institutions matter for order and development. These are the unwritten rules and practices that govern everyday behavior, social interactions, market activity, and property rights. ${ }^{1}$ In cases where formal justice is absent or overloaded, informal systems resolve disputes and provide property rights. This describes many low-income countries, especially rural regions and fragile states emerging from conflict. Even in strong states, however, informal systems resolve everyday conflict most of the time, albeit in the shadow of the law (e.g. Azari and Smith 2012).

Policymakers frequently try to shape and strengthen informal institutions. This raises several questions. Can more just, equal, or peaceful systems be engineered? Are there unintended consequences? And will better micro-level institutions promote local development?

This paper presents the short- and long-term impacts of an attempt to engineer better informal institutions in post-war rural Liberia. In 2009-10, the government of Liberia, the United Nations (UN), and various civil society organizations conducted a large-scale alternative dispute resolution (ADR) campaign. ADR is a set of informal practices of mediation and negotiation that are intended to help parties reach self-enforcing bargains (Mnookin 1998; Lieberman and Henry 1986). It tries to establish a shared language and practice of dispute resolution, improve communication, and contain emotion, keeping people at the bargaining table. It also tries to shape local social norms to discourage parties to a conflict from breaking bargains or using violence.

In some respects this parallels the way conflict is modeled in international relations. Violence in village disputes is viewed as a form of bargaining breakdown that results from commitment problems, asymmetric information, and deviations from rational decision-making, such as emotional outbursts. ADR fosters skills and norms to help disputants behave more rationally, exchange information, and commit to negotiated or mediated solutions. ${ }^{2}$

We worked with implementers to set up the ADR intervention as a randomized controlled trial. The government nominated 246 eligible communities, 85 of which were assigned to and received the ADR training. In these locations, implementers invited a sixth of all adults to participate in eight days of training spread over several months, including extensive coaching and practice in ADR. The implementers trained more than 12,000 people in 2009-10. This mass education approach was based on the idea that community education shifts knowledge,

\footnotetext{
${ }^{1} \mathrm{~A}$ common definition of informal institutions is the shared unwritten rules of appropriate behavior enforced through social sanction and praise, and through neocustomary or "traditional" mechanisms of adjudication and dispute resolution (Ellickson 1991; Knight 1992; North 1990).

${ }^{2}$ There are close parallels between ADR at the micro level and how international relations scholars conceive of peace mediation and why it is effective (Beber 2012).
} 
skills, and norms, resulting in behavior change.

In previous work, we reported impacts roughly one year after the average community was treated (Blattman et al. 2014). Most communities had a lingering backlog of unresolved disputes. Consistent with improved bargaining, the intervention reduced the number of unresolved disputes by $29 \%$. There were also some indications of a decrease in violence related to these disputes, but after one year these results were generally not statistically significant.

This paper assesses longer term impacts on a broader range of outcomes and mechanisms. We collected new data three years after the average community received the campaign. On the one hand, this allows more time for institutional changes to set in. On the other hand, achieving persistent change in conflict norms is difficult. It is one thing to change dispute practices in the short term, and another to change the informal rules that govern communities in the long run.

Two years after the first endline survey, in 2013, we returned to collect data on over 7,500 plots of town and farm land, including information about disputes, property security, and investments. We also collected data on ADR knowledge, skills, and norms from over 4,000 community residents. We first look at whether short-term effects on the resolution and severity of disputes persist over time. Second, we look for effects that may take more than a year to materialize, especially property rights security and investment. Third, we investigate potential mechanisms, which were not measured in our 1-year survey. Finally, we explore the program's long-term impact on power differentials within communities - an important source of property rights insecurity in West Africa (Goldstein and Udry 2008; Besley and Ghatak 2009).

We highlight seven sets of results. First, disputes are ever-present, and treatment has little apparent effect on the incidence of disputes at either endline. Second, treatment reduces the number of persistent and hard-to-resolve in the first year. We do not see any increase in the speed or level of dispute resolution after three years. One reason might be that the backlog of longstanding disputes was dealt with in the first year.

Third and most important, after three years we see a significant drop in hostilities and violence associated with disputes - land, business, and interpersonal. For instance, about half of all land disputes involve angry threats, property destruction (like trampling crops), and interpersonal violence (like fistfights). In treated communities, a land dispute is about $40 \%$ less likely to involve any of these hostilities at the three year endline.

Fourth, we find no evidence that more peaceful dispute resolution increased perceived security of property rights and investment. We expected that stronger informal dispute resolution systems might improve residents' property rights security and increase their will- 
ingness to make costly investments in their homes and farms. A large political economy literature suggests the right to investment returns shapes investment incentives (Besley and Ghatak 2009; Goldstein and Udry 2008), although hard evidence is still emerging. ${ }^{3}$ After one year we did not find any effect on security or investment, but we hypothesized that such an effect might take longer to realize. We find no evidence that it did, and some evidence of a negative effect on property rights in the long term.

Fifth, this average effect masks important variation. Villagers with established tenure or political connections reported better security as a result of the intervention. Poorer respondents, less politically connected individuals, and people with farm plots owned by other villagers all felt slightly less secure in treatment villages - an adverse effect that seems to further disadvantage those who are already vulnerable. We have to take these sub-group analyses with some caution, as they were not pre-specified. Nonetheless, our results are consistent with other studies showing that informal institutions can favor the powerful and well-connected (Isser et al. 2009), and that these individuals tend to invest more and have higher output (Goldstein and Udry 2008; Besley and Ghatak 2009). ${ }^{4}$

Sixth, our results suggest that ADR worked in part because it promoted norms of nonviolence, especially managing of emotions, and hence made it easier to reach self-enforcing peaceful bargains. This is in line with our interpretation of ADR through the lens of noncooperative bargaining theory. We were unable to test this interpretation directly in our 1-year analysis, since we lacked direct measures of skill and norms change. For the 3-year endline, we developed a battery of questions on resolution skills and norms. We see some evidence of a persistent change in skills related to managing emotions and avoiding violence, as well as norms and attitudes around violent behavior.

Finally, our evidence suggests that ADR mass education would be more cost-effective if implementers could find a more efficient system of imparting new skills and norms. The intervention was funded with a $\$ 1.2$ million grant. We need to make many assumptions to estimate the cost per violent dispute avoided, but reasonable estimates suggest that the intervention "breaks even" after three years only if avoiding a violent dispute is worth an amount equal to twice the average Liberian's annual income. Even for a proof-of-concept

\footnotetext{
${ }^{3}$ New experimental work in Benin by Goldstein et al. (2015) suggests that interventions targeting property rights insecurity, such as demarcation, can induce investment in previously insecure plots.

${ }^{4}$ We must weigh these findings against the advantages of informal institutions, which previous research shows may be as good or better than formal governance mechanisms under certain conditions. Ostrom (1990)'s classic work on governing common resources demonstrates how communal governance mechanisms can lead to better outcomes for all community members. Tsai (2007) and Xu and Yao (2015) show how informal mechanisms of accountability, including moral authority, can increase public goods provision in China. Dispute resolution through informal institutions is often quicker, cheaper, and more accessible than through formal ones, especially in places where the police and courts are corrupt or dysfunctional (Isser et al. 2009).
} 
trial, this is a relatively high cost to avoid only moderately intense violence. Moving ahead, we believe implementers ought to test the effectiveness of programs that use information technology or other means to deliver cheaply at scale.

Taken together, our results suggest that engineering better informal institutions is feasible but costly, and risks some unintended consequences. On the one hand, the persistent decline in violence associated with disputes and the change in norms around managing emotions and avoiding violence shows that it is possible to improve bargaining behavior and avoid breakdown. This is remarkable given that the intervention lasted only two months in each village, and given that we measured outcomes a full three years after implementation.

On the other hand, the program's differential effects suggest that strengthening informal institutions could reinforce existing inequalities in power and security. The program's steep price tag gives further cause for concern. These results offer a more nuanced understanding of the advantages and limitations of attempts to re-engineer informal institutions, and also demonstrate the usefulness of assessing the durability of institutional change over time - a rarity for evaluations of this kind.

\section{Setting}

Liberia is a small West African nation and one of the poorest countries in the world, ranking below the 7th percentile of all countries on the Human Development Index, including Afghanistan and the Democratic Republic of Congo (Jahan 2016). Between 1989 and 2003, two civil wars killed hundreds of thousands and displaced a majority of the population. Many factors contributed to the conflict, including over-centralized political power, ethnic and class tensions, and struggles over land and natural resource rights. ${ }^{5}$ A 2003 agreement ushered in peace, and three democratic elections ensued. Events in this paper stretch from 2008 to 2012, five years after the end of the civil war and two years before the outbreak of Ebola. This was a time of relative stability and economic growth.

\subsection{Property and property rights}

Small-holder agriculture provides the livelihood for most rural Liberians. Farmers depend on rain-fed subsistence crops of rice, cassava, and vegetables (Corriveau-Bourque 2010), while tree crops (e.g. coffee and cocoa) and rubber production supplement income. ${ }^{6}$ Land is often

\footnotetext{
${ }^{5}$ See Ellis (2006); Richards (2005); Sawyer (2005); Levitt (2005) for a more comprehensive discussion of the role conflict over property and natural resources played in the civil war.

${ }^{6}$ The median farm size reported in our survey is 7.5 acres, which is large, though not unreasonably so. Note that this includes the entire area of the most important farm, not the area under cultivation. Technology
} 
a household's most important asset (Boone 2014; Baldwin 2015).

Outside the coastal zone and major towns, Liberian law recognizes a customary system of property rights. Under this regime, communities exercise collective ownership rights over the land (Alden-Wiley 2007; Boone 2014). Local leaders administer property on behalf of the community, and can assign temporary use of a plot for growing food. Leaders can also assign long-term rights of use that can be passed down within a family.

As in other parts of West Africa, political influence and connections in the community shape what rules apply (Berry 2009; Boone 2014). For instance, land access and long-term rights are typically based on real or imagined ties to indigenous or first-comer status in a village. Historically, "neocustomary" systems have also tended to provide more secure rights to older men, and those from the majority ethnic group. Women, youth, members of minority groups, and the politically unconnected can find themselves at a disadvantage.

Land rights are often contested. Households may lay claim to the same plot of land, or may have different understandings of the type and length of use they have been granted. Natural boundaries (the most common type of boundary) may change over time, leading to disagreements. Confusion over property rights law also gives people the opportunity to act in bad faith (Stevens 2014). Liberia is rife with tales of "double-selling" and fraudulent documents. These too create the conditions for disputes.

Most of these issues are magnified by fourteen years of political instability and violence, 1989-2003. Violence displaced nearly the entire rural population of the country for years. Written records were destroyed, and oral records were often lost when community leaders or elders were displaced, emigrated, or died. Upon returning home, people naturally used the most convenient or productive land, regardless of historical rights. This aggravated disputes over borders and inheritance, which became a key challenge in the post-war era. In 2011, $16 \%$ of all households nationwide reported a land dispute since the war's end, and $10 \%$ reported another major dispute, such as over money or inheritance (Vinck et al. 2011).

\subsection{Dispute resolution}

Liberians seldom use the formal courts to resolve property disputes. This is especially true outside the major towns, and in cases that do not involve serious crimes. Police and court systems were slowly rebuilding after the war, and they remain expensive, inefficient, and often corrupt (M'Cormack 2017; Unruh 2009; Isser et al. 2009).

As a result, informal institutions are the dominant way local disputes are resolved in

Liberia. Almost three-quarters of respondents with land disputes in our sample sought to

for measuring property sizes is not easily available in most of the study area, leading to error in respondent estimations. 
resolve their dispute with an informal authority. Local leaders, family members, neighbors, and the parties themselves mediate and negotiate. While this system can be cheap and effective, it has limitations. Nationwide, roughly $40 \%$ of land disputes and $16 \%$ of non-land disputes recorded in 2011 remained unresolved (Vinck et al. 2011, 61). Nationally, 20\% of disputes eventually turned violent (p. 49). Nearly half of land disputes in our study communities involved some form of threats or aggression.

Most of this violence is low-level and limited: trampling of crops, defacement, fist fights, and so forth. Sometimes tit-for-tat reprisals escalate into greater and greater violence, however. The government of Liberia and UN peacekeepers have long been concerned that these local incidents could spark a national crisis. This, too, has occurred in our study areas. In 2008, for instance, a dispute over farmland between two politicians erupted into widespread violence. In 2010 the mysterious death of a girl in one of our control villages escalated into countywide ethnic riots and political strain.

\section{The intervention}

In response to these challenges, in 2008 the United Nations High Commission for Refugees (UNHCR) and an NGO, the Justice and Peace Commission (JPC) proposed a mass education program that would promote alternative dispute resolution (ADR) in Liberian towns and villages. ADR is a set of informal practices and norms of negotiation and mediation. It is intended to help parties reach self-enforcing bargains faster than courts (Mnookin 1998; Lieberman and Henry 1986). UNHCR and JPC referred to the program as "peace education".

The implementers set out to recruit about a sixth of adults into training workshops in each community. Each workshop involved eight days of training in groups of 35 residents, led by two facilitators. Training days were spread over two months, allowing trainees to practice in between. Workshops were fairly homogenous across communities. There was no public information campaign to the broader community outside of the workshops. But the implementers hoped for the skills, practices, and norms to spread by example and word of mouth.

The curriculum emphasized specific ADR tools, skills, and practices, including: (i) direct engagement in one's own or others' disputes; (ii) strategies for problem solving and negotiation; (iii) face-saving and "positive-sum" resolutions; (iv) avoidance of forum shopping and the formal justice system; and (v) strategies to avoid anger, threats, and violence, plus norms against all of these. Workshops combined lectures with group discussion, participatory dramas, and opportunities for people to share experiences. Sessions drew on a wide range of examples, including community and group conflicts, but emphasized interpersonal 
conflicts, especially land, money, domestic, and neighbor disputes.

UNHCR and JPC not only targeted leaders who already mediated many disputes, but also strongly encouraged and trained ordinary residents to negotiate their own disputes or mediate disputes amongst neighbors. This push for everyday negotiation and mediation was a major theme. The implementers did not want to create a greater backlog of disputes for local leaders or elites.

Facilitators typically lived and slept in communities on weekdays for the full 2-3 months. They ran the workshops almost continuously, given how many adults had to pass through each day of training. After-hours interactions with participants provided an opportunity to demonstrate, facilitate, and reinforce the ideas and norms taught in workshops. Facilitators seldom played a direct role in disputes as mediators, however. The principal treatment seemed to be the workshop.

\subsection{Sample selection}

UNHCR and JPC worked in 3 of Liberia's 15 counties: Lofa, Nimba, and Grand Gedeh. These are denser and more war-affected regions, and were expected to have more disputes and weaker social bonds. With the support of JPC and UNHCR, county officials nominated 246 communities they felt could benefit from the intervention, ranging in size from 100 to 5000 persons. Officials tried to select what they believed to be "conflict-prone" communities. But compared to national data, our sample is not extreme, with rates of land conflict only moderately higher than the national average (Vinck et al. 2011).

Within treated communities, facilitators and community leaders mobilized residents for the training in various ways. This included community leader recommendations, self-nominations, and door-to-door canvasing. On average, community members who participated in the workshops look much like those who did not. Comparing pre-intervention traits shows that minority status had little association with attendance, nor did several of the strongest correlates

of land conflict - having your land or house taken during the war, having been a refugee or displaced, or being a victim of war violence. However, trainees were slightly more likely to be older, male, lifetime residents with land.

\section{Theoretical frame and predictions}

\subsection{ADR through the lens of noncooperative bargaining}

We view disputes in Liberia as classic problems of non-cooperative bargaining with no third party to enforce resolutions. In this view, bargaining breakdowns result from incomplete 
information and commitment problems. Failure to resolve disputes may also be caused by parties' lack of trust and their resulting failure to communicate, or their assumption that negotiation is a zero-sum game, encouraging them to bluff, mislead, and use strong-arm tactics to gain advantage (Deutsch et al. 2011). These are classic bargaining failures, most commonly used to understand labor disputes and international conflict (Kennan and Wilson 1993; Fearon 1995, 1998), but directly applicable to interpersonal conflicts as well.

Disputants may also behave irrationally: they are often loss averse; they assume their preferences are incompatible with others; they undervalue concessions and miss mutually advantageous moves; they allow conflict to escalate even when the optimal decision would be to change strategy; and they hold self-serving recall biases accentuated by ambiguous information (Bazerman et al. 2000; Kahneman et al. 1991). Emotion can exacerbate these problems, slowing the bargaining process and increasing the length of disputes and the risk of violence.

We view ADR as an attempt to solve these bargaining problems. ADR aims to reduce the length and cost of disputes and to improve the quality of outcomes (Lieberman and Henry 1986). It does so by imparting skills and practices (how to resolve disputes) and fostering norms (how people ought to resolve disputes) that should, in principle, improve communication, foster mutual understanding, and build trust in negotiation and third party mediation.

More specifically, ADR aims to reduce imperfect information by promoting empathy, honesty, open communication, and active listening. It encourages disputants to be aware of their own biases and to seek mutually advantageous bargains, thus mitigating commitment problems. And it attempts to activate mechanisms of social sanction or praise by stigmatizing defection from whatever agreement the parties reach.

ADR can thus be understood as a "technology" of dispute resolution relayed through short, repeated training sessions. By establishing new norms and skills, ADR provides a new framework for informally resolving disputes, and thus a new informal institution. But new informal institutions do not emerge in a vacuum. ADR inevitably interacts with existing mechanisms for regulating behavior and resolving disputes, and this interaction may undermine the very goals that ADR seeks to achieve.

\subsection{Unintended consequences}

ADR training might have a number of unintended and perhaps adverse effects. ADR encourages parties to seek a mediated solution outside of the courts, which may result in more efficient bargaining, but may also allow powerful individuals to prevent other parties from 
seeking redress in venues where they might receive fairer treatment. Those in privileged positions may also use ADR to legitimate biased decisions reached through existing informal institutions. And because bargains reached through ADR are by nature unenforceable (Sternlight 2006), they may only accentuate local power imbalances. In short, ADR may produce quick and inexpensive resolutions, but there is no guarantee it will produce fair ones (Edwards 1986, 679).

New informal institutions may also simply fail to take hold, especially if they threaten the existing social and political hierarchy. New rules and mechanisms of social enforcement are inherently uncertain, and communities may fail to coordinate on them (Knight 1992). And while the literature on norm diffusion suggests that education can produce a "cascade effect" through which new norms spread from influential actors to the rest of the group (e.g. Kuran 1997), norms tend to be sticky, and the mechanisms of social sanction and praise that sustain them can prevent individuals from abandoning old norms or adopting new ones, even if they would otherwise like to (Cloward 2014).

\subsection{Predictions}

After one year we expected to find an increase in the durability of bargains and, given a decrease in the probability of bargaining breakdowns, a reduction in violence as first order outcomes. Our 3-year survey looks for persistent impacts on the same outcomes, and for a longer-term shift towards the skills, practices, and norms emphasized in the ADR curriculum. To the extent that dispute resolution improves, we also expected to see improvements in perceived security of property rights, particularly around land, and increased investment and economic activity. However, we also expected that social and demographic characteristics might influence the extent to which particular sub-groups benefitted from the treatment.

\section{$5 \quad$ Empirical strategy and data}

\subsection{Experimental design}

We randomized assignment to the ADR intervention, as well as the timing and intensity of treatment. Of the 246 eligible communities, we stratified by county and randomly assigned 116 to treatment. Communities were widely spread across space, with little risk of spillovers between them.

Implementation occurred over 21 months, from March 2009 to November 2010. We randomized the order of treatment into five phases. We did this mainly to guard against unanticipated interruptions, which indeed occurred. UNHCR ran out of funds and stopped 
the intervention in Phase 4. To estimate treatment effects, we pool the Phase 5 communities into the control group for a total of 160 control communities.

In addition, because of implementation delays, a small number of communities received the intervention at the same time as the first endline survey. Most of these "late treatment" communities were in Phase 4, and we selected them randomly for late treatment. Our one-year treatment effects estimates account for them (see below).

We also assigned 16 of the 86 treatment communities (26 of the original 116) to an "intense" treatment, with 30 to $40 \%$ more workshops. We did this in order to assess the marginal effect of increased training beyond the NGO's 15\% target. Nonetheless, our main focus was on the treatment-control comparison.

As we show in the appendix, random assignment produced the expected degree of balance along covariates. Table A.1 reports means for a selection of 41 baseline covariates by experimental assignment. For the most part, background attributes appear balanced across experimental conditions. There are some minor differences between treatment and control communities: 3 of the 41 mean differences $(7 \%)$ have $p<.1$. Overall the imbalance is consistent with chance and is robust to alternative balance tests.

\subsection{Data and main outcomes}

Shortly before program implementation, we conducted a baseline survey, in March-April 2009. We collected endline data one and three years later on average. The first endline ran from November 2010 to January 2011-19 months after the first community received the training, and 10.6 months after the average community received the training. The second endline ran from February to April 2013 - 44 months after the first community received the training, and 35.6 months after the average community received the training. For simplicity we refer to the two surveys as the 1-year and 3-year endlines.

In each round, we surveyed quasi-random cross-sections of roughly 20 residents per community. We selected households by using the "random route" method (described in detail in the appendix). Non-response was typically less than 5 to $10 \%$ per community; nonresponding households were replaced with a neighbor. To measure community-level outcomes and traits, we also surveyed four leaders at baseline and each endline - typically a town chief and a female, youth, and minority leader. We use the average response for continuous measures and the modal response for indicators.

The 1-year endline collected data in 243 of the 246 communities. (Two extremely remote villages could not be reached by surveyors, and one tiny village disbanded before the endline. All three were in the control group.) The 3-year endline collected data in 204 of the 245 
communities still in existence in 2012. Due to budget constraints and the disproportionate number of control villages, we dropped s a selection of 40 control communities that were most dissimilar from treatment, stratified by county. Given the high fixed cost of reaching each village, this was the most cost-effective means to maximize statistical power and minimize bias.

Both endline surveys pre-date the development of the social science registry, and so primary and secondary outcomes were not pre-registered. The published 1-year results effectively pre-specify primary outcomes for the 3-year analysis, however. Thus this paper focuses first and foremost on land dispute outcomes (incidence, resolution, and violence, with new information on dispute length and details of any violence). As in the previous paper, we also examine a broader set of business and interpersonal disputes. The 3-year survey also added questions on a number of secondary outcomes: property security, investment, and skills and norms of dispute resolution. While these were not formally pre-specified, they were explicitly mentioned in the previous paper as outcomes of interest.

\subsection{Estimation}

We estimate program impacts by calculating intent-to-treat (ITT) estimates via the weighted least squares regression:

$$
Y_{i j}=\theta T_{j}+\beta X_{i j}+\alpha_{d}+\epsilon_{i j}
$$

where $Y_{i j}$ denotes the outcome for respondent $i$ in community $j ; T_{j}$ is an indicator for assignment to treatment; $X_{i j}$ is a set of baseline covariates; $\alpha_{d}$ are district fixed effects; and $\epsilon_{i j}$ is an individual error term, clustered by community. When outcomes are binary, this linear probability model approach to ITT estimation is standard, as it simplifies interpretation of the treatment effects without materially affecting the efficiency or accuracy of the ITT.

In the 3-year endline, we weight communities by the inverse probability of selection into the endline sample. ${ }^{7}$ In the 1-year results only, $X$ also includes an indicator for the handful of Phase 4 treatment villages that were randomly assigned to be treated concurrently with the first endline survey. Our tables focus on the main treatment effect, $\theta$, which averages communities treated 25-44 months beforehand in the 3-year survey, and 1-19 months beforehand in the 1-year survey.

\footnotetext{
${ }^{7}$ This specification differs from the previously published results in that we estimate an intent-to-treat effect (ITT) rather than a complier average causal effect (CACE). The CACE estimator allowed us to account for concurrent treatment, but this is no longer relevant 3 years after the intervention. Our results are substantively unchanged regardless.
} 
All outcome measures are self-reported. If training leads to social desirability bias (so that residents under-report disputes, or repeat back norms), we will overestimate treatment effects. While this is a risk, the pattern of effects we observe is inconsistent with social desirability bias: while some treatment effects are consistent with the messages of the intervention (e.g. positive effects on norms prohibiting the use of violence), others are not (e.g. null effects on norms related to bias, defection, and empathy). These nulls provide reassurance that the significant effects we observe are not artifacts of social desirability bias alone. Moreover, given the length of time between the intervention and the 3-year endline, it is implausible that social desirability bias persisted without any actual change in underlying norms, skills and behaviors.

\section{Results}

\subsection{Dispute resolution}

Land disputes We begin, in Table 1, with the primary outcomes of the one-year study: the incidence, severity and resolution of land disputes. At each endline, we asked respondents whether they had any "serious dispute" over land in the past year, including any that had already been resolved. More than a fifth of households reported a land dispute in the first endline; this had fallen to just under one in ten by the three-year endline. This decline may reflect the natural resolution of disputes arising from mass displacement and return, though we do not have the data or research design to be sure. Treatment, however, does not appear to affect the incidence of disputes. This is largely consistent with our theoretical predictions: disputes are ever present, and ADR was designed to help manage them peacefully, not eliminate them entirely.

We then asked if the dispute had been resolved by the time of the survey. About a third remained unresolved in both endlines. After one year, the proportion of residents with an unresolved land dispute fell by 2 percentage points in treatment communities, a $28 \%$ reduction versus the control group. Conditional on having a dispute, we observed a $10.5 \%$ increase in the rate of resolution after one year in treatment communities. We see no evidence of a continued decrease in unresolved disputes after three years, however, nor do we see a decrease in dispute length (a new measure). In the previously published study, we speculated that the program was especially effective in resolving the most serious and longstanding disputes, since the largest effect was in the subset of disputes that involved property taken during the civil war. That we fail to find an effect on dispute resolution after three years may reflect the fact that there were fewer of these serious longstanding disputes 
Table 1: Program impacts on number, length, severity, and resolution of land disputes

\begin{tabular}{|c|c|c|c|c|c|c|c|c|}
\hline \multirow{3}{*}{ Dependent Variable } & \multicolumn{4}{|c|}{ 1-year endline } & \multicolumn{4}{|c|}{ 3-year endline } \\
\hline & $\begin{array}{l}\text { Control } \\
\text { mean }\end{array}$ & ITT & SE & $\begin{array}{c}\text { ITT / } \\
\text { control } \\
\text { mean } \\
(\%)\end{array}$ & $\begin{array}{l}\text { Control } \\
\text { mean }\end{array}$ & ITT & $\mathrm{SE}$ & $\begin{array}{c}\text { ITT / } \\
\text { control } \\
\text { mean } \\
(\%)\end{array}$ \\
\hline & (1) & (2) & (3) & (4) & (5) & (6) & (7) & (8) \\
\hline \multicolumn{9}{|l|}{ Outcomes for all residents $(N=4,011)$} \\
\hline Any serious dispute & 0.221 & 0.003 & 0.016 & 1.2 & 0.087 & 0.008 & 0.011 & 9.3 \\
\hline Any unresolved dispute & 0.07 & -0.02 & $0.008^{* *}$ & -28 & 0.024 & 0.002 & 0.005 & 6.4 \\
\hline Any dispute with threats, property destruction, or interpersonal violence & 0.122 & -0.01 & 0.012 & -8.1 & 0.041 & -0.012 & $0.006^{* *}$ & -28.4 \\
\hline \multicolumn{9}{|l|}{ Conditional on a dispute occurring ( $N=353)$} \\
\hline Length of dispute (months) & & & & & 13.247 & 3.628 & 2.885 & 27.4 \\
\hline Resolved dispute & 0.684 & 0.072 & $0.027^{* * *}$ & 10.5 & 0.668 & -0.024 & 0.046 & -3.6 \\
\hline Resolved via informal mechanism & 0.193 & 0.032 & 0.024 & 16.4 & 0.251 & 0.031 & 0.051 & 12.3 \\
\hline Any threats, property destruction, or interpersonal violence & 0.554 & -0.024 & 0.035 & -4.3 & 0.476 & -0.193 & $0.047^{* * *}$ & -40.6 \\
\hline Any property damage or violence & 0.411 & -0.037 & 0.03 & -9.1 & 0.243 & -0.091 & $0.042^{* *}$ & -37.5 \\
\hline Any threats & 0.515 & -0.013 & 0.035 & -2.5 & 0.408 & -0.159 & $0.048^{* * *}$ & -38.9 \\
\hline Any property destruction & 0.186 & -0.051 & $0.025^{* *}$ & -27.4 & 0.114 & -0.068 & $0.027^{* *}$ & -59.3 \\
\hline Any violence & 0.349 & -0.022 & 0.028 & -6.3 & 0.202 & -0.057 & 0.042 & -28.5 \\
\hline
\end{tabular}

Notes: Intent-to-treat (ITT) effects with baseline covariates and district fixed effects. Columns 1-4 report results for the 1-year endline; columns 5-8 report results for the 3-year endline. Estimates are weighted by the inverse probability of sampling. Standard errors are clustered by community. ${ }^{* * *} p<0.01,{ }^{* *} p<0.05,{ }^{*} p<0.1$. Ns are 5,435 for 1 -year endline regressions with all residents and 1,212 for 1-year endline regressions conditional on a dispute. Ns are 4,011 and 353 at 3-year endline for regressions for all residents and conditional on a dispute, respectively.

left to resolve.

We do, however, see evidence of a large long-term reduction in hostility and violence associated with land disputes. At both endlines, roughly half of all land disputes involved threats, destruction of property, or interpersonal violence. After one year, respondents in treatment communities were 1 percentage point less likely to report a dispute involving threats or violence (an 8\% decrease relative to the control group), but this decline was not statistically significant. Conditional on a dispute, there was some evidence of a significant decline in property destruction, but effects on one subcategory of violence have to be taken with caution.

Three years after the intervention, treatment effects are larger and more robust. Respondents in treatment communities were 1.2 percentage points (28\%) less likely to report any threats or violence. Conditional on having a dispute, respondents were 19 percentage points (41\%) less likely to report threats, property destruction, or interpersonal violence, and 9 percentage points $(37 \%)$ less likely to report property destruction or interpersonal violence. We see substantial proportional reductions in all three forms of hostility, though the fall in interpersonal violence alone is not statistically significant. 
Table 2: Program impacts on number, length, severity, and resolution of all dispute types

\begin{tabular}{|c|c|c|c|c|c|c|c|c|}
\hline \multirow{3}{*}{ Dependent Variable } & \multicolumn{4}{|c|}{ 1-year endline } & \multicolumn{4}{|c|}{ 3-year endline } \\
\hline & $\begin{array}{l}\text { Control } \\
\text { mean }\end{array}$ & ITT & SE & $\begin{array}{c}\text { ITT / } \\
\text { control } \\
\text { mean } \\
(\%)\end{array}$ & $\begin{array}{l}\text { Control } \\
\text { mean }\end{array}$ & ITT & $\mathrm{SE}$ & $\begin{array}{c}\text { ITT / } \\
\text { control } \\
\text { mean } \\
(\%)\end{array}$ \\
\hline & (1) & (2) & (3) & (4) & (5) & (6) & (7) & (8) \\
\hline \multicolumn{9}{|l|}{ Outcomes for all residents } \\
\hline Any serious dispute & 0.299 & 0.022 & 0.018 & 7.2 & 0.306 & 0.012 & 0.017 & 4 \\
\hline Any unresolved dispute & 0.118 & -0.013 & 0.011 & -11 & 0.064 & -0.005 & 0.009 & -7.1 \\
\hline Any dispute with threats, property destruction, or interpersonal violence & & & & & 0.101 & -0.015 & 0.01 & -15.2 \\
\hline \multicolumn{9}{|l|}{ Conditional on a dispute occurring } \\
\hline Length of dispute (months) & & & & & 6.052 & 1,227 & 1.159 & 0.788 \\
\hline Resolved dispute & 0.676 & 0.051 & $0.024^{* *}$ & 7.5 & 0.767 & -0.018 & 0.026 & -2.3 \\
\hline Resolved via informal mechanism & 0.247 & 0.018 & 0.025 & 7.4 & 0.409 & -.019 & 0.027 & -4.6 \\
\hline Any threats, property destruction, or interpersonal violence & & & & & 0.331 & -0.068 & $0.026^{* * *}$ & -20.7 \\
\hline Any property damage or interpersonal violence & & & & & 0.19 & -0.027 & 0.022 & -14.1 \\
\hline Any threats & & & & & 0.274 & -0.072 & $0.024^{* * *}$ & -26.2 \\
\hline Any property destruction & & & & & 0.048 & -0.02 & $0.011^{*}$ & -40.5 \\
\hline Any violence & & & & & 0.173 & -0.018 & 0.021 & -10.2 \\
\hline
\end{tabular}

Notes: Intent-to-treat (ITT) effects with baseline covariates and district fixed effects. Columns 1-5 report results for the 1-year endline; columns 6-10 report results for the 3-year endline. Estimates are weighted by the inverse probability of sampling. Standard errors are clustered by community. ${ }^{* * *} p<0.01,{ }^{* *} p<0.05,{ }^{*} p<0.1$. Ns are 5,435 for 1 -year endline regressions with all residents and 1671 for 1-year endline regressions conditional on a dispute. Ns are 4,011 and 1,227 at 3-year endline for regressions for all residents and conditional on a dirpute, respectively.

Land, money, and interpersonal disputes We observe similar patterns looking at land, money, and interpersonal disputes together, in Table 2. After one year, $30 \%$ of control community respondents reported at least one of these disputes. We see roughly the same number of disputes after three years, though this may be due to our inclusion of a much more detailed measure of domestic disputes in the 3-year endline. At 1-year endline, respondents in treatment communities were 2 percentage points more likely to report a dispute, an increase of $7 \%$ relative to the control group, though this difference was not statistically significant. Disputants in treatment communities were also 5 percentage points $(7.5 \%)$ more likely to report a resolution. After three years, as with land disputes, we see no statistically significant increase in disputes or resolutions.

We do, however, see a long-run reduction in dispute severity. After three years, one-third of disputes in control communities involved property destruction or interpersonal violence; in treatment communities, this proportion dropped by almost 7 percentage points - a $21 \%$ decline relative to control.

\subsection{Land security and investment}

We found no evidence that the ADR campaign increased investment or improved security of property rights at the 1-year endline, and hypothesized that not enough time had passed for community members to realize these benefits. At the 3-year endline, we measured four 
Table 3: Effect on land security and investment, 3-year endline

\begin{tabular}{lccc}
\hline Dependent Variable & $\mathrm{N}$ & Control Mean & ITT \\
& $(1)$ & $(2)$ & $(3)$ \\
\hline Security rights index for house and farm & 4,011 & 0.045 & -0.083 \\
& & & {$[0.037]^{* *}$} \\
Improvement index for house and farm & 4,011 & 0.023 & -0.065 \\
& & & {$[0.037]^{*}$} \\
Index of fallow land for farm & 3,666 & 0.003 & -0.003 \\
& & & {$[0.044]$} \\
Size of farm (acres) & 3,598 & 37.481 & 2.75 \\
& & & {$[1.051]^{* * *}$} \\
\hline
\end{tabular}

Notes: 3-year intent-to-treat (ITT) effects with baseline covariates and district fixed effects. Estimates are weighted by the inverse probability of sampling. Standard errors are clustered by community. ${ }^{* * *} p<0.01,{ }^{* *} p<0.05,{ }^{*} p<0.1$. Not all respondents tend to plots, which causes varying Ns across variables.

dimensions of property rights: inheritance, alienation, collateralization, and demarcation. We measured respondents' beliefs about their ability to exercise each of these rights over a particular plot of land. ${ }^{8}$ We also collected data on farm size, willingness to leave farmland fallow, ${ }^{9}$ capital improvements (such as fences, gutters, and grass), and money and time spent on improvements. We use these measures to construct standardized indices of security rights, improvements, and fallowing, as well as a measure of farm size.

Table 3 reports results, which are mixed. On the one hand, treatment community residents reported farm plots 2.75 acres larger than the control community average. ${ }^{10}$ On the other hand, when we consider farm and house plots together, we find that plots in treatment communities score .08 standard deviations lower on our index of security rights. Respondents in treatment communities also scored almost .065 standard deviations lower on our improvement index. In particular, treatment community respondents reported being less certain that their property boundaries will not be overstepped, and less certain that they can extend inheritance rights to people of their choosing. These results run counter to our expectations. Respondents report weak property rights overall, and the treatment appears to have weakened them further.

\footnotetext{
${ }^{8}$ We asked respondents to identify their "most important" house plot within the community, their most important farm plot, and any other plots with disputes associated with them. Very few respondents reported more than one dispute, and the majority of disputes took place on the most important house or farm plot.

${ }^{9}$ The ability to fallow is one dimension of tenure security in this context (Goldstein and Udry 2008).

${ }^{10}$ Our average plot sizes are large for the region, but we ask respondents about the size of their plot, rather than the area under cultivation, so as to include land acquired as an investment.
} 
Table 4: Heterogeneity in land security and investment, 3-year endline

\begin{tabular}{|c|c|c|c|c|c|c|c|c|c|}
\hline \multirow{4}{*}{ Dependent variable } & \multicolumn{9}{|c|}{ Heterogeneity by: } \\
\hline & \multicolumn{3}{|c|}{ Political Connectedness } & \multicolumn{3}{|c|}{ Market Tenure } & \multicolumn{3}{|c|}{ Land Ownership } \\
\hline & $\begin{array}{l}\text { Coeff. on } \\
\text { treatment }\end{array}$ & $\begin{array}{l}\text { Coeff. on } \\
\text { treatment- } \\
\text { covariate } \\
\text { interaction }\end{array}$ & Sum & $\begin{array}{l}\text { Coeff. on } \\
\text { treatment }\end{array}$ & $\begin{array}{l}\text { Coeff. on } \\
\text { treatment- } \\
\text { covariate } \\
\text { interaction }\end{array}$ & Sum & $\begin{array}{l}\text { Coeff. on } \\
\text { treatment }\end{array}$ & $\begin{array}{l}\text { Coeff. on } \\
\text { treatment- } \\
\text { covariate } \\
\text { interaction }\end{array}$ & Sum \\
\hline & (1) & (2) & (3) & (4) & (5) & (6) & (7) & (8) & (9) \\
\hline \multirow[t]{2}{*}{ Security rights index } & -0.124 & 0.14 & 0.015 & -0.128 & 0.083 & -0.044 & -0.085 & 0.059 & -0.026 \\
\hline & {$[0.037]^{* * *}$} & {$[0.058]^{* *}$} & {$[0.047]$} & {$[0.063]^{* *}$} & {$[0.067]$} & {$[0.031]$} & {$[0.031]^{* * *}$} & {$[0.076]$} & {$[0.072]$} \\
\hline \multirow[t]{2}{*}{ Improvement index } & -0.045 & -0.022 & -0.067 & -0.012 & -0.043 & -0.055 & -0.048 & -0.017 & -0.065 \\
\hline & {$[0.031]$} & {$[0.054]$} & {$[0.046]$} & {$[0.050]$} & {$[0.054]$} & {$[0.029]^{*}$} & {$[0.028]^{*}$} & {$[0.064]$} & {$[0.060]$} \\
\hline \multirow[t]{2}{*}{ Size of plot } & 2.214 & 1.488 & 3.702 & 2.715 & -0.206 & 2.509 & 3.235 & -3.151 & 0.085 \\
\hline & {$[1.136]^{*}$} & {$[1.956]$} & {$[1.653]^{* *}$} & {$[2.082]$} & {$[2.302]$} & {$[1.056]^{* *}$} & {$[1.034]^{* * *}$} & {$[2.515]$} & [2.329] \\
\hline
\end{tabular}

Notes: 3-year heterogeneous treatment effects by political connectedness, market tenure, and land ownership, with baseline covariates and district fixed effects. Estimates are weighted by the inverse probability of sampling. Standard errors are clustered by community. ${ }^{* * *} p<0.01,{ }^{* *} p<0.05,{ }^{*} p<0.1$.

\subsection{Heterogeneity in land security by political connections}

What explains these apparently adverse effects? As discussed above and in our previous study, informal institutions might favor the powerful, and strengthening them might benefit those who already occupy privileged positions. If this is the case, then the declines in security and property improvements should be concentrated among those with the least power in their communities.

To explore this possibility, Table 4 reports three separate heterogeneity analyses, interacting treatment with three measures of status related to land:

1. An indicator for strong political connections (measured as a kin relationship with the town chief),

2. An indicator for market-based ownership of the plot (i.e. whether the respondent acquired ownership through a market transaction, which tends to endow stronger rights than customary allocation), and

3. An indicator for owning land, rather than renting or borrowing.

We measured these variables with the intention of studying heterogeneity, but they were not pre-specified. Hence we must interpret results with some caution.

With that caveat in mind, treatment effects on security rights do appear to depend on status. With the addition of the interaction terms above, the coefficient on the treatment indicator is now interpreted as the effect on the low-powered, and the coefficient on the interaction term is the difference between the low and high-powered. Thus a negative treatment 
effect and a positive interaction suggests that low-powered individuals bear the brunt of the decline in property security.

This is generally what we see, though the interaction is not always statistically significant. The fall in security rights is concentrated among politically unconnected individuals, those without market-based tenure, and those who do not own their land (columns 1, 4, and 7). The effects on security rights are null among residents with political connections, those with market-based tenure, and those who own their land (columns 3, 6, and 9).

The other results are more mixed. Relative to control, all treatment community residents were less likely to make improvements to their plots, regardless of their status (though these effects are generally not statistically significant, and generally not statistically different between higher and lower status individuals). And all treatment group residents had larger farm plots relative to control, though this effect is more pronounced among politically connected individuals (column 3) and those with market tenure (column 6). Interestingly, this effect is also more pronounced among those who do not own their land (column 7), perhaps because renting land is less expensive than buying.

\subsection{Norms, attitudes and skills}

To better understand how the ADR campaign worked, we asked respondents about their experiences and perspectives on informal dispute resolution as it was taught during the intervention. We focused on: (i) descriptive dispute resolution norms in the community, such as whether it is the norm for people to try to resolve disputes directly with the other party before involving outside authorities; (ii) respondents' attitudes toward these norms, such as their opinion of resolving a dispute directly with the other party; and (iii) respondents' dispute resolution skills, such as whether they tried to resolve a dispute directly with another party in the last year. Survey questions for measuring these outcomes were developed after extensive study of dispute resolution practices in treatment and control communities. (Hartman 2015).

Table 5 reports effects on indices of these norms, attitudes, and skills. Each index contains between five and 10 survey questions, grouped thematically and added and standardized to have zero mean and unit standard deviation. More positive values indicate greater alignment with the messages of the training. For example, more positive values on the defection index indicate greater alignment with the norm that disputants should abide by the bargains they reach. We look at leader responses as well as responses from the sample of community members.

In general, we observe little change in these norms, attitudes, and skills. We find some 
Table 5: Effect on norms, attitudes and skills, 3-year endline

\begin{tabular}{lcccc}
\hline & & & & \\
Dependent Variable (z-score) & Control Mean & ITT & Control Mean & ITT \\
& $(1)$ & $(2)$ & $(3)$ & $(4)$ \\
\hline Bias index & -0.009 & -0.003 & 0.068 & -0.107 \\
& & {$[0.046]$} & & {$[0.088]$} \\
Defection index & -0.043 & 0.042 & 0.004 & -0.1 \\
& & {$[0.041]$} & & {$[0.079]$} \\
Empathy index & 0.002 & 0.031 & 0.067 & -0.022 \\
& & {$[0.033]$} & & {$[0.067]$} \\
Forum choice index & -0.028 & 0.03 & -0.048 & 0.005 \\
& & {$[0.037]$} & & {$[0.088]$} \\
Managing emotions index & -0.031 & 0.069 & 0.032 & -0.039 \\
& & {$[0.031]^{* *}$} & & {$[0.078]$} \\
Mediation index & 0.003 & -0.061 & 0.006 & -0.036 \\
& & {$[0.037]^{*}$} & & {$[0.074]$} \\
Negotiation index & 0.002 & 0.003 & 0.047 & -0.059 \\
& & {$[0.027]$} & & {$[0.069]$} \\
\hline
\end{tabular}

Notes: 3-year intent-to-treat (ITT) effects with baseline covariates and district fixed effects. Columns 1-3 report results for randomly-selected residents; columns 4-6 report results for purposively-sampled leaders. Estimates for residents are weighted by the inverse probability of sampling. Standard errors are clustered by community. ${ }^{* * *} p<0.01,{ }^{* *} p<0.05,{ }^{*} p<0.1$. Ns are 4,011 for residents and 971 for leaders.

suggestive evidence that norms around mediation are actually weaker in treatment communities, though this effect is only marginally statistically significant. We do, however, find more robust evidence that treatment community residents internalized norms around managing emotions and avoiding violence. While we must treat these results with caustion, as they will be sensitive to multiple comparisons corrections, they are consistent with our finding that the program did not reduce the incidence, length, or resolution of disputes in the long term, but that it did reduce the prevalence of violence associated with them.

\subsection{Community-level disputes}

Table 6 reports impacts on community-level disputes. After one year, the ADR campaign led to increases in witch hunts and disputes between elders and youths. Youth-elder disputes increased by almost $40 \%$ (or 4 percentage points) over the control group mean of $11 \%$. 
More striking, witch hunts nearly doubled, from $1.5 \%$ to $3.8 \%$ - an increase of $153 \%$. In our previous study we interpreted this as troubling evidence that greater informality can have the unintended consequence of encouraging communities to adjudicate disputes outside the bounds of the law. These two effects together drove a 19\% (8.5 percentage point) increase in the prevalence of any violence at the community-level.

These effects did not endure over time. The difference in community-level disputes between treatment and control communities is no longer significant after three years. If anything, in most cases disputes declined (though most of these results are not statistically significant). For example, incidents of intertribal violence, already a rare event, fell by 1.6 percentage points $(78 \%)$ in treatment communities. Witch hunts fell by .1 percentage point $(72 \%)$ in treatment communities as well. We view this latter result as especially important given the spike in witch hunts after one year.

On the other hand, violent strikes and protests increased by 1.6 percentage points, which represents a substantively huge (albeit only marginally statistically significant) $912 \%$ increase over the control group mean. Peaceful strikes and protests increased as well, though not statistically significantly. It is possible that the program induced treatment communities residents to be more proactive in protesting actions they disapproved of - even violently. ${ }^{11}$ But this is speculative, and ultimately we cannot be sure. Whatever the explanation, these community-level results suggest that the potential for adverse effects continues to be a serious concern, even as individual-level disputes around land, money, and other interpersonal issues become increasingly peaceful over time.

\subsection{Aggregate impacts}

How much violence did the program actually reduce, and at what cost? We can approximate the aggregate impact on violence by multiplying our treatment effects at each endline by the roughly 30,000 households living in the 86 treatment communities. We do not have an estimate for the year between the two endlines, but can interpolate that gap year by multiplying the total disputes by $1.5 .^{12}$

\footnotetext{
${ }^{11}$ Our qualitative work suggests that protests in rural Liberian communities often target unpopular decisions by local leaders (such as levying a local fee or tax or implementing a community labour requirement) or the actions of foreign companies extracting natural resources, or are related to friction between ethnoreligious groups or frustration with government's lack of progress in resolving criminal cases.

${ }^{12}$ The census suggests these 86 communities have roughly 240,000 residents in total, and the survey respondents report an average houshehold size of 8 . As an alternative to this simple back-of-the-envelope method, we can also perform a weighted comparison of the number of conflicts reported in treatment and control communities, where each observation is weighted to account for the fact that (1) the fraction of the population surveyed varied across communities; (2) some communities were dropped from the 3-year endline; and (3) survey questions about conflicts in the past year refer to different periods of time, depending on when the survey was conducted. We obtain roughly similar results, and thus opt for the simpler and more
} 
Table 6: Effect on community-level disputes

\begin{tabular}{|c|c|c|c|c|c|c|c|c|}
\hline \multirow{3}{*}{ Dependent Variable } & \multicolumn{4}{|c|}{ 1-year endline } & \multicolumn{4}{|c|}{ 3-year endline } \\
\hline & $\begin{array}{l}\text { Control } \\
\text { mean }\end{array}$ & ITT & $\mathrm{SE}$ & $\begin{array}{c}\text { ITT / } \\
\text { control } \\
\text { mean } \\
(\%)\end{array}$ & $\begin{array}{l}\text { Control } \\
\text { mean }\end{array}$ & ITT & $\mathrm{SE}$ & $\begin{array}{c}\text { ITT / } \\
\text { control } \\
\text { mean } \\
(\%)\end{array}$ \\
\hline & $(1)$ & $(2)$ & $(3)$ & $(4)$ & $(5)$ & $(5)$ & $(7)$ & $(8)$ \\
\hline Any Violence & 0.442 & 0.085 & $0.037^{* *}$ & 19.3 & 0.622 & -0.057 & 0.057 & -9.1 \\
\hline Level of community disputes & 0.79 & 0.152 & $0.083^{*}$ & 19.2 & 0.984 & -0.131 & 0.096 & -13.3 \\
\hline Intertribal violence & 0.028 & 0.008 & 0.013 & 30 & 0.021 & -0.016 & $0.008^{* *}$ & -77.8 \\
\hline Violent strike or protest & 0.061 & -0.004 & 0.016 & -7.1 & 0.002 & 0.015 & 0.009 & 912.4 \\
\hline Youth-elder dispute & 0.11 & 0.044 & 0.029 & 40.2 & 0.103 & 0.003 & 0.023 & 3.4 \\
\hline Peaceful strike or protest & 0.1 & 0.037 & 0.025 & 37.1 & 0.059 & 0.01 & 0.019 & 16 \\
\hline Interfamily land disputes & 0.0 .274 & 0.030 & 0.037 & 11.1 & 0.548 & -0.071 & 0.066 & -12.9 \\
\hline Conflicts with other towns & 0.154 & -0.005 & 0.033 & -3.5 & 0.171 & -0.038 & 0.029 & -22.2 \\
\hline Witch hunts & 0.015 & 0.023 & $0.013^{*}$ & 153.3 & 0.011 & -0.008 & $0.005^{*}$ & -71.8 \\
\hline Trial by ordeal & 0.048 & 0.019 & 0.018 & 39.4 & 0.07 & -0.027 & 0.018 & -39.1 \\
\hline
\end{tabular}

Notes: 3-year intent-to-treat (ITT) effects with baseline covariates and district fixed effects. Outcomes are measured at the community level using leaders' reports. ${ }^{* * *} p<0.01,{ }^{* *} p<0.05,{ }^{*} p<0.1$. Ns are 940 for 1-year endline and 971 for 3 -year endline.

Table 7: Estimated aggregate effects of the program on violent disputes among the 30,000 households in treatment communities

\begin{tabular}{|c|c|c|c|c|c|}
\hline \multirow[b]{2}{*}{ Dependent variable } & \multicolumn{2}{|c|}{ ITT } & \multicolumn{2}{|c|}{ Net effect } & \multirow{2}{*}{$\begin{array}{l}\text { Sum, in- } \\
\text { terpolating } \\
\text { the gap } \\
\text { year }\end{array}$} \\
\hline & $\begin{array}{l}\text { 1-year } \\
\text { endline }\end{array}$ & $\begin{array}{l}\text { 3-year } \\
\text { endline }\end{array}$ & $\begin{array}{l}\text { 1-year } \\
\text { endline }\end{array}$ & $\begin{array}{l}\text { 3-year } \\
\text { endline }\end{array}$ & \\
\hline Land disputes only & (1) & $(2)$ & $(3)$ & $(4)$ & $(5)$ \\
\hline Threats & -0.006 & -0.010 & -183 & -264 & -671 \\
\hline Property destruction & -0.013 & -0.005 & -406 & -139 & -818 \\
\hline Interpersonal violence & -0.007 & -0.004 & -206 & -95 & -451 \\
\hline Property destruction or interpersonal violence & -0.012 & -0.006 & -365 & -171 & -805 \\
\hline Property damage + interpersonal violence & -0.020 & -0.009 & -611 & -235 & $-1,269$ \\
\hline
\end{tabular}


Table 7 reports our results. These are conservative estimates in the sense that we only know if at least one dispute resulted in a violent act. We do not know if more than one violent act of the same type occurred, and these aggregate effects assume they do not. Also, we interviewed one adult per household, about all household disputes. But households had 8 members on average, with multiple adults, and to the extent that the respondent forgot or was not aware of a brother's, spouse's or parent's dispute, they may underreport violence.

We estimate that the program resulted in 671 fewer angry threats and 805 fewer disputes with property destruction or interpersonal violence. If we treat property destruction and interpersonal violence as separate incidents, we estimate that the program led to 1,269 fewer acts of violence (excluding threats). The program cost $\$ 1.2$ million to implement in all 86 villages. ${ }^{13}$ This transaltes to a cost of $\$ 946$ for every act of property destruction or interpersonal violence. This is more than twice Liberia's income per capita. Even if lives are saved, this is likely to be considerably more expensive than other potentially life-saving foreign aid investments.

\section{$7 \quad$ Discussion and conclusions}

Like most developing or fragile states, property and other kinds of disputes are endemic in rural Liberia. A large number of these involve incidents of low-level violence, with a smaller number escalating from there. We find that a relatively short but intensive mass education program died not affect the prevalence of disputes, but did reduce the likelihood of violence associated with them. These effects last at least three years, suggesting that negotiation and mediation behavior are malleable over the long term.

On the one hand this is an impressive feat of social engineering. We began this study optimistic about ADR's potential to solve bargaining problems, but skeptical of the elitedriven, "push" approach to behavior change chosen by the implementers. Somewhat to our surprise, our results suggest that a push approach can yield a lasting reduction in violence over time, perhaps through changes in norms, attitudes, and skills related to emotional regulation and the appropriateness of violence.

Improving formal justice systems in weak states is slow and challenging. Our findings point to a potentially replicable strategy for reducing the risks and costs associated with small-scale disputes through mass education and ADR outside the formal sector. The program we evaluate was expensive to deliver, but lower-cost alternatives may be feasible, and

transparent method reported here.

${ }^{13}$ This includes all adminstrative costs, all expenses lost to the delays, and many of the start-up costs associated with scaling this program for the first time. Scaling further could create economies of scale. Hence the $\$ 1.2$ million cost is conservative as a cost denominator. 
are worth exploring. Radio, television, primary and secondary school curricula, and other mass media could bring the technology of ADR to a much wider community.

On the other hand, social engineering may have unintended consequences. After one year, we found that the intervention increased reliance on extrajudicial punishment, particularly witch hunts and trial by ordeal. While these effects decayed over time, we find evidence of other adverse consequences in the long term, including an increase in violent strikes and protests. Strengthening informal institutions also seems to have secured the property rights of some over others, resulting in a net decrease in security of property rights in treatment communities.

This result is not entirely surprising. Political power structures property rights (e.g. Goldstein and Udry 2008; Boone 2014), and it is unsurprising that the program failed to change political power structures at the local level. But this finding has important implications for development and humanitarian programs that seek sustainability by building on existing rules, norms, and practices. Given that these existing systems may disadvantage certain groups, such interventions may have perverse effects. Further work is needed to evaluate the cost and desirability of shifting local power structures towards greater inclusivity.

Our results have important implications for the study of conflict as well. Non-cooperative bargaining theory is one of the most common frameworks for understanding conflict crossnationally. We show that a theory originally intended to explain interstate wars can be usefully applied to interpersonal disputes as well. Further research on micro-level bargaining breakdowns, both rational and irrational, strikes us as an important and under-explored frontier.

Finally, our study demonstrates the benefits of testing the long-term effects of interventions of this sort. These interventions are cost- and labor-intensive, and aim to deliver large-scale changes that may not be immediately detectable. Yet most evaluations assess only short-term effects, generating little knowledge about whether such investments lead to persistent change. Finding cost-effective ways to assess the long-term impact of programs, successful or not, will help to produce clearer guidance on how best to invest in durable change. 


\section{References}

Alden-Wiley, L. (2007). Who Owns the Forest? Technical report, Sustainable Development Institute, Monrovia, Liberia. https://goo.gl/Hyao3y.

Azari, J. R. and J. K. Smith (2012). Unwritten Rules: Informal Institutions in Established Democracies. Perspectives on Politics 10(1), 37-55.

Baldwin, K. (2015). The Paradox of Traditional Chiefs in Democratic Africa. New York: Cambridge University Press.

Bazerman, M., J. Curhan, D. Moore, and K. Valley (2000). Negotiation. Annual Review of Psychology, 279-314.

Beber, B. (2012). International mediation, selection effects, and the question of bias. Conflict Management and Peace Science 29(4), 397-424.

Berry, S. (2009). Property, Authority and Citizenship: Land Claims, Politics and the Dynamics of Social Division in West Africa. Development and Change 40(1), 23-45.

Besley, T. J. and M. Ghatak (2009). Property rights and economic development. In D. Rodick and M. Rozensweig (Eds.), The Handbook of Development Economics, Volume 5. North Holland.

Blattman, C., A. C. Hartman, and R. A. Blair (2014). How to promote order and property rights under weak rule of law? An experiment in changing dispute resolution behavior through community education. American Political Science Review 108(1), 100-120.

Boone, C. (2014, February). Property and Political Order in Africa: Land Rights and the Structure of Politics. New York: Cambridge University Press.

Cloward, K. (2014). False commitments: local misrepresentation and the international norms against female genital mutilation and early marriage. International Organization 68(3), $495-526$.

Corriveau-Bourque, A. (2010). Confusions and Palava: The Logic of Land Encroachment in Lofa County, Liberia. Canadian Journal of Development Studies 31(1-2), 27-48.

Deutsch, M., P. T. Coleman, and E. C. Marcus (2011). The Handbook of Conflict Resolution: Theory and Practice. John Wiley \& Sons. 
Edwards, H. T. (1986). Alternative Dispute Resolution: Panacea or Anathema? Harvard Law Review 99(3), 668-684.

Ellickson, R. C. (1991). Order Without Law. Cambridge: Harvard University Press.

Ellis, S. (2006). The Mask of Anarchy: The Destruction of Liberia and the Religious Dimension of an African Civil War. New York: New York University Press.

Fearon, J. D. (1995). Rationalist explanations for war. International Organization 49(03), $379-414$.

Fearon, J. D. (1998). Bargaining, Enforcement, and International Cooperation. International Organization 52(2), 269-305.

Goldstein, M., K. Houngbedji, F. Kondylis, M. O’Sullivan, and H. Selod. Formalisation des droits fonciers dans les zones rurales d'afrique de l'ouest. World Bank Group Working Paper (7435). https://goo.gl/eNEbCn.

Goldstein, M. and C. Udry (2008). The Profits of Power: Land Rights and Agricultural Investment in Ghana. Journal of Political Economy 116(6), 981-1022.

Hartman, A. (2015). Property Rights Under Pressure: Conflict Over Land in Liberia. Ph. D. thesis, Yale University, New Haven.

Isser, D. H., S. C. Lubkemann, and S. N'Tow (2009). Looking for Justice: Liberian Experiences with and Perceptions of Local Justice Options. Washington, DC: United States Institute for Peace.

Jahan, S. (2016). Human Development Report 2016. Technical report, United Nations Development Programme, New York. https://goo.gl/tUKW98.

Kahneman, D., J. L. Knetsch, and R. H. Thaler (1991). Anomalies: The endowment effect, loss aversion, and status quo bias. The journal of economic perspectives, 193-206.

Kennan, J. and R. Wilson (1993). Bargaining with Private Information. Journal of Economic Literature $31(1)$, 45-104.

Knight, J. (1992). Institutions and social conflict. New York: Cambridge University Press.

Kuran, T. (1997). Private Truths, Public Lies: The Social Consequences of Preference Falsification. Harvard University Press. 
Levitt, J. I. (2005). The evolution of deadly conflict in Liberia: from 'paternaltarianism' to state collapse. Durham: Carolina Academic Press.

Lieberman, J. and J. Henry (1986). Lessons from the Alternative Dispute Resolution Movement. University of Chicago Law Review 53(2).

M'Cormack, F. I. (2017). Traditional Justice Mechanisms in Liberia. Technical report, Analyse Societale Africaine. https://goo.gl/PLPTe2.

Mnookin, R. H. (1998). Alternative dispute resolution. Technical report, Harvard Law School. https://goo.gl/jtWi7S.

North, D. C. (1990). Institutions, institutional change, and economic performance. The Political economy of institutions and decisions. New York: Cambridge University Press.

Ostrom, E. (1990, November). Governing the Commons: The Evolution of Institutions for Collective Action. New York: Cambridge University Press.

Richards, P. (2005). To fight or to farm? Agrarian dimensions of the Mano River conflicts (Liberia and Sierra Leone). African Affairs 104(417), 571-590.

Sawyer, A. (2005). Beyond plunder: toward democratic governance in Liberia. Lynne Rienner Publishers.

Sternlight, J. R. (2006). Is Alternative Dispute Resolution Consistent with the Rule of Law - Lessons from Abroad. DePaul Law Review 56, 569.

Stevens, C. J. (2014). The Legal History of Public Land in Liberia. Journal of African Law 58(02), 250-265.

Tsai, L. L. (2007). Solidary Groups, Informal Accountability, and Local Public Goods Provision in Rural China. American Political Science Review 101(2), 355-372.

Unruh, J. D. (2009). Land rights in postwar Liberia: The volatile part of the peace process. Land Use Policy 26(2), 425-433.

Vinck, P., P. Pham, and T. Kreutzer (2011). Talking Peace: A Population-Based Survey on Attitudes About Security, Dispute Resolution, and Post-Conflict Reconstruction in Liberia. Berkeley: UC Berkeley Human Rights Center.

Xu, Y. and Y. Yao (2015). Informal Institutions, Collective Action, and Public Investment in Rural China. American Political Science Review 109(02), 371-391. 


\section{Online Appendix}

\section{A.1 Random route sampling method}

We sampled survey respondents using the random route method. Typically there is no village census from which to sample in rural Liberia. Thus interviewers were assigned a starting location (the center of the village, or the center of a town quarter in larger towns) and provided with a set of random walking rules: to spin a pen to select a direction, to use a paper-based random number generator to choose house number $n$, to select the $n$th house in that direction for a survey, and to select an adult in that household to interview at random. This does not produce a representative sample of the community, but it does sample community members similarly across the treatment arms.

\section{A.2 Descriptive statistics and balance test}

Table A.1 reports means for a selection of 41 baseline covariates by experimental assignment. For the most part, background attributes appear balanced across experimental conditions. There are some minor differences between treatment and control communities: 3 of the 41 mean differences $(7 \%)$ have $p<.1$. Overall the imbalance is consistent with chance and is robust to alternative balance tests.

\section{A.3 Intent-to-treat effects for intense treatment}

Here we explore the effect of intense treatment on our outcomes of interest. Recall that 16 of the 85 treatment communities received an intense treatment of 30-40\% more workshops. Table A.2 reports impacts by intensity. At the 1-year endline we saw little effect of treatment intensity on our main outcomes of interest. At the 3-year endline we find that intense treatment leads to a reduction in treatment respondents reporting threats or violence.

\section{A.4 Heterogeneous treatment effects}

Table A.3 reports heterogeneous treatment effects on land disputes and resolution along gender, age, wealth, religion, ethnicity, prior (pre-treatment) exposure to peace education, and current (post-treatment) membership in a peace group. In general, we see little evidence of treatment effect heterogeneity. The most obvious exception is that the program appears 
Table A.1: 2008 baseline summary statistics and test of randomization balance

\begin{tabular}{|c|c|c|c|c|c|}
\hline & \multicolumn{3}{|c|}{ Mean } & \multicolumn{2}{|c|}{ Regression difference } \\
\hline & All & Treatment & Control & Coeff. & p-value \\
\hline Resident Demographics & $(1)$ & $(2)$ & $(3)$ & $(4)$ & $(5)$ \\
\hline Age & 40.7 & 40.3 & 40.9 & 0.50 & 0.44 \\
\hline Male & 0.56 & 0.56 & 0.57 & 0.00 & 0.91 \\
\hline Years of education & 5.2 & 5.1 & 5.3 & 0.04 & 0.87 \\
\hline Muslim & 0.12 & 0.12 & 0.12 & 0.01 & 0.76 \\
\hline Traditional religion & 0.05 & 0.04 & 0.05 & 0.01 & 0.27 \\
\hline Christian Dummy & 0.84 & 0.84 & 0.83 & 0.02 & 0.52 \\
\hline Wealth index & 0.01 & 0.01 & 0.01 & 0.05 & 0.30 \\
\hline Landless & 0.13 & 0.15 & 0.13 & 0.01 & 0.50 \\
\hline No farm & 0.07 & 0.08 & 0.06 & 0.01 & 0.54 \\
\hline Prior peace education & 0.28 & 0.30 & 0.27 & 0.03 & 0.32 \\
\hline Participating in a peace group & 0.40 & 0.37 & 0.41 & -0.03 & 0.19 \\
\hline \multicolumn{6}{|l|}{ Resident War Experiences } \\
\hline 1 if refugee & 0.58 & 0.58 & 0.58 & 0.02 & 0.48 \\
\hline 1 if displaced & 0.43 & 0.48 & 0.40 & 0.08 & 0.01 \\
\hline All violence experienced index $(0-13)$ & 4.2 & 4.2 & 4.3 & 0.19 & 0.33 \\
\hline \multicolumn{6}{|l|}{ Resident Land and Interpersonal Conflict } \\
\hline House spot or farm land taken during war & 0.10 & 0.10 & 0.10 & 0.00 & 0.96 \\
\hline Any land conflict since end of war & 0.24 & 0.22 & 0.26 & 0.03 & 0.20 \\
\hline Had a money conflict in 2008 & 0.09 & 0.09 & 0.08 & 0.01 & 0.41 \\
\hline Any burglary or armed robbery in 2008 & 0.13 & 0.13 & 0.14 & 0.01 & 0.59 \\
\hline Victim of witchcraft in 2008 & 0.09 & 0.07 & 0.10 & 0.02 & 0.16 \\
\hline Had a dispute at the water source in past 6 mo. & 0.08 & 0.08 & 0.08 & 0.00 & 0.70 \\
\hline \multicolumn{6}{|l|}{ Town-level characteristics } \\
\hline Town population & 2,026 & 2,056 & 2,010 & 88 & 0.60 \\
\hline Town education level & 5.2 & 5.1 & 5.2 & 0.06 & 0.82 \\
\hline Number of tribes in town & 2.6 & 2.9 & 2.5 & 0.48 & 0.03 \\
\hline$\%$ of community members in largest tribe & 0.82 & 0.80 & 0.83 & 0.03 & 0.31 \\
\hline Town wealth index & 0.02 & 0.01 & 0.03 & 0.05 & 0.31 \\
\hline \# of services available in town $(0-14)$ & 5.61 & 5.45 & 5.70 & 0.23 & 0.52 \\
\hline \# of resources within 2 hrs. of comm. (0-5) & 1.45 & 1.52 & 1.41 & 0.11 & 0.28 \\
\hline Distance to nearest road in hours, rainy season & 1.07 & 1.07 & 1.08 & 0.02 & 0.92 \\
\hline Town exposure to war violence & 4.28 & 4.19 & 4.33 & 0.16 & 0.43 \\
\hline Proportion of town losing land during war & 0.10 & 0.10 & 0.11 & 0.00 & 0.73 \\
\hline Index of progressive political beliefs in town & 3.85 & 3.84 & 3.85 & 0.01 & 0.88 \\
\hline Index of progressive ethnic attitudes in town & 5.78 & 5.73 & 5.81 & 0.09 & 0.55 \\
\hline \multicolumn{6}{|l|}{ Town-level crime and conflict events in 2008} \\
\hline$\%$ of town with prior peace education & 0.28 & 0.30 & 0.27 & 0.03 & 0.23 \\
\hline$\%$ of town participating in a peace group & 0.40 & 0.38 & 0.41 & -0.03 & 0.33 \\
\hline$\%$ of town accepting inter-religious marriage & 0.66 & 0.67 & 0.66 & 0.01 & 0.59 \\
\hline$\%$ of town reporting assault & 0.19 & 0.18 & 0.19 & 0.01 & 0.56 \\
\hline Proportion of town reporting land dispute & 0.24 & 0.22 & 0.25 & 0.03 & 0.33 \\
\hline$\%$ of town reporting witchcraft victimization & 0.09 & 0.07 & 0.10 & 0.03 & 0.09 \\
\hline$\%$ of town reporting violent dispute at water source & 0.05 & 0.06 & 0.05 & 0.01 & 0.61 \\
\hline Peaceful strike or protest in town & 0.07 & 0.06 & 0.07 & 0.01 & 0.74 \\
\hline Violent strike or ethnic dispute in town & 0.10 & 0.07 & 0.12 & 0.05 & 0.20 \\
\hline Witch killing or trial by ordeal in town & 0.09 & 0.10 & 0.09 & 0.02 & 0.68 \\
\hline Rape or murder in town & 0.15 & 0.16 & 0.15 & 0.02 & 0.74 \\
\hline
\end{tabular}


Table A.2: Effects of intense treatment

\begin{tabular}{|c|c|c|c|c|c|c|}
\hline & \multicolumn{3}{|c|}{ 1-year endline } & \multicolumn{3}{|c|}{ 3-year endline } \\
\hline & $\begin{array}{l}\text { Coeff. on } \\
\text { assignment to } \\
\text { normal } \\
\text { treatment } \\
(1)\end{array}$ & $\begin{array}{l}\text { Coeff. on } \\
\text { assignment to } \\
\text { intensive } \\
\text { treatment } \\
(2)\end{array}$ & $\begin{array}{l}\text { Net effect of } \\
\text { intensive } \\
\text { treatment } \\
(3)\end{array}$ & $\begin{array}{l}\text { Coeff. on } \\
\text { assignment to } \\
\text { normal } \\
\text { treatment } \\
(4)\end{array}$ & $\begin{array}{l}\text { Coeff. on } \\
\text { assignment to } \\
\text { intensive } \\
\text { treatment } \\
(5)\end{array}$ & $\begin{array}{l}\text { Net effect of } \\
\text { intensive } \\
\text { treatment } \\
(6)\end{array}$ \\
\hline Attended program & $\begin{array}{c}0.251 \\
{[0.023]^{* * *}}\end{array}$ & $\begin{array}{c}0.086 \\
{[0.045]^{*}}\end{array}$ & $\begin{array}{c}0.336 \\
{[0.040]^{* * *}}\end{array}$ & & & \\
\hline Any land dispute & $\begin{array}{c}0.01 \\
{[0.018]}\end{array}$ & $\begin{array}{c}-0.03 \\
{[0.030]}\end{array}$ & $\begin{array}{c}-0.02 \\
{[0.028]}\end{array}$ & $\begin{array}{c}0.007 \\
{[0.012]}\end{array}$ & $\begin{array}{l}-0.014 \\
{[0.016]}\end{array}$ & $\begin{array}{l}-0.007 \\
{[0.014]}\end{array}$ \\
\hline Land dispute resulted in any threats or violences & $\begin{array}{l}-0.008 \\
{[0.013]}\end{array}$ & $\begin{array}{l}-0.008 \\
{[0.021]}\end{array}$ & $\begin{array}{l}-0.016 \\
{[0.019]}\end{array}$ & $\begin{array}{c}-0.012 \\
{[0.007]^{*}}\end{array}$ & $\begin{array}{l}-0.006 \\
{[0.009]}\end{array}$ & $\begin{array}{c}-0.019 \\
{[0.007]^{* * *}}\end{array}$ \\
\hline Security rights index, aggregated & & & & $\begin{array}{c}-0.081 \\
{[0.044]^{*}}\end{array}$ & $\begin{array}{c}0.007 \\
{[0.063]}\end{array}$ & $\begin{array}{l}-0.074 \\
{[0.053]}\end{array}$ \\
\hline Improvement index, aggregated & & & & $\begin{array}{l}-0.064 \\
{[0.039]}\end{array}$ & $\begin{array}{c}0.025 \\
{[0.061]}\end{array}$ & $\begin{array}{l}-0.038 \\
{[0.056]}\end{array}$ \\
\hline
\end{tabular}

Notes: 3-year heterogeneous treatment effects by intensity of treatment, with baseline covariates and district fixed effects. Communities randomly assigned to intense treatment received 30 to $40 \%$ more workshops. Columns $1-3$ report results for the 1-year endline; columns 4-6 report results for the 3-year endline. Estimates are weighted by the inverse probability of sampling. Standard errors are clustered by community. ${ }^{* * *} p<0.01,{ }^{* *} p<0.05, * p<0.1$.

to have increased the prevalence of unresolved land disputes among ethnic and religious minorities (column 3), both in absolute terms and relative to non-minorities.

\section{A.5 Component variables for norms, attitudes and skills indices}

We used a battery of 49 survey questions to measure attitudes, skills and norms. We organize these questions into six thematic areas: (1) Bias, (2) Defection, (3) Forum Choice, (4) Managing Emotions and Avoiding Violence, (5) Mediation, and (6) Negotiation. These six categories reflect core areas of the ADR curriculum used during the intervention. We formulated questions on attitudes to identify the respondent's opinion about a particular behavior (for example: Do you think that it is good idea to ask friends for help when resolving a dispute?). For questions that focused on skills, we asked whether respondents actually practiced a specific behavior themselves (for example: Do you help to cool other people's temper during a dispute?). Finally, for questions that covered descriptive norms, we asked questions about community behavior, not specifically about the respondent (for example: In this community do people take sides during disputes because one of the parties is their friend?). 
Table A.3: Heterogeneity by demographics and peace background on conflict

\begin{tabular}{|c|c|c|c|c|c|c|c|c|}
\hline & \multicolumn{8}{|c|}{ Dependent Variable } \\
\hline & \multicolumn{2}{|c|}{$\begin{array}{l}\text { Any land serious } \\
\text { dispute }\end{array}$} & \multicolumn{2}{|c|}{$\begin{array}{l}\text { Any unresolved land } \\
\text { dispute }\end{array}$} & \multicolumn{2}{|c|}{$\begin{array}{c}\text { Property destruction } \\
\text { conditional on land } \\
\text { dispute }\end{array}$} & \multicolumn{2}{|c|}{ Resolved land dispute } \\
\hline & $\begin{array}{l}\text { Coeff. } \\
\text { (1) }\end{array}$ & $\begin{array}{l}\mathrm{SE} \\
(2)\end{array}$ & $\begin{array}{c}\text { Coeff. } \\
(3)\end{array}$ & $\begin{array}{l}\text { SE } \\
(4)\end{array}$ & $\begin{array}{l}\text { Coeff. } \\
(5)\end{array}$ & $\begin{array}{l}\mathrm{SE} \\
(6) \\
\end{array}$ & $\begin{array}{l}\text { Coeff. } \\
(7)\end{array}$ & $\begin{array}{l}\text { SE } \\
(8)\end{array}$ \\
\hline \multicolumn{9}{|l|}{ Female } \\
\hline Treatment & -0.001 & {$[0.015]$} & 0.005 & {$[0.008]$} & -0.009 & {$[0.004]^{* *}$} & -0.062 & {$[0.066]$} \\
\hline Interaction & 0.017 & {$[0.018]$} & -0.008 & {$[0.010]$} & 0.008 & {$[0.005]$} & 0.082 & {$[0.100]$} \\
\hline Sum & 0.016 & {$[0.013]$} & -0.002 & {$[0.006]$} & -0.002 & {$[0.004]$} & 0.02 & {$[0.070]$} \\
\hline \multicolumn{9}{|l|}{ Aged 20-40 } \\
\hline Treatment & 0.014 & {$[0.014]$} & 0.005 & {$[0.006]$} & -0.002 & {$[0.004]$} & -0.133 & {$[0.075]^{*}$} \\
\hline Interaction & -0.012 & {$[0.017]$} & -0.006 & {$[0.009]$} & -0.007 & {$[0.005]$} & 0.201 & {$[0.109]^{*}$} \\
\hline Sum & 0.002 & {$[0.013]$} & -0.002 & {$[0.007]$} & -0.009 & {$[0.004]^{* *}$} & 0.068 & {$[0.069]$} \\
\hline \multicolumn{9}{|l|}{ Wealth } \\
\hline Treatment & 0.008 & {$[0.011]$} & 0.002 & {$[0.005]$} & -0.005 & {$[0.003]^{*}$} & -0.021 & {$[0.045]$} \\
\hline Interaction & -0.016 & {$[0.017]$} & -0.011 & {$[0.008]$} & -0.004 & {$[0.004]$} & -0.082 & {$[0.074]$} \\
\hline Sum & -0.008 & {$[0.021]$} & -0.01 & {$[0.009]$} & -0.009 & {$[0.005]^{*}$} & -0.102 & {$[0.090]$} \\
\hline \multicolumn{9}{|c|}{ Muslim minority } \\
\hline Treatment & 0.009 & {$[0.011]$} & -0.002 & {$[0.005]$} & -0.005 & {$[0.003]^{*}$} & -0.013 & {$[0.048]$} \\
\hline Interaction & -0.01 & {$[0.026]$} & 0.03 & {$[0.012]^{* *}$} & 0.001 & {$[0.007]$} & -0.178 & {$[0.139]$} \\
\hline Sum & -0.001 & {$[0.024]$} & 0.028 & {$[0.012]^{* *}$} & -0.004 & {$[0.006]$} & -0.191 & {$[0.129]$} \\
\hline \multicolumn{9}{|c|}{ Any ethnic minority } \\
\hline Treatment & 0.01 & {$[0.011]$} & -0.001 & {$[0.005]$} & -0.005 & {$[0.003]$} & -0.007 & {$[0.050]$} \\
\hline Interaction & -0.013 & {$[0.026]$} & 0.025 & {$[0.013]^{* *}$} & -0.003 & {$[0.008]$} & -0.161 & {$[0.139]$} \\
\hline Sum & -0.004 & {$[0.024]$} & 0.023 & {$[0.012]^{*}$} & -0.008 & {$[0.007]$} & -0.168 & {$[0.129]$} \\
\hline \multicolumn{9}{|c|}{ Prior peace education } \\
\hline Treatment & 0.013 & {$[0.021]$} & 0.008 & {$[0.009]$} & -0.005 & {$[0.005]$} & 0.04 & {$[0.109]$} \\
\hline Interaction & -0.013 & {$[0.048]$} & -0.019 & {$[0.021]$} & -0.001 & {$[0.012]$} & -0.165 & {$[0.250]$} \\
\hline Sum & 0 & {$[0.032]$} & -0.01 & {$[0.014]$} & -0.006 & {$[0.008]$} & -0.124 & {$[0.156]$} \\
\hline
\end{tabular}


Table A.4: Heterogeneity by demographics and peace background on security and investment

\begin{tabular}{|c|c|c|c|c|c|c|c|c|}
\hline & \multicolumn{8}{|c|}{ Dependent Variable } \\
\hline & \multicolumn{2}{|c|}{$\begin{array}{l}\text { Security rights index, } \\
\text { aggregated }\end{array}$} & \multicolumn{2}{|c|}{$\begin{array}{l}\text { Improvement index, } \\
\text { aggregated }\end{array}$} & \multicolumn{2}{|c|}{$\begin{array}{c}\text { Index of fallow land, } \\
\text { farm }\end{array}$} & \multicolumn{2}{|c|}{ Size of farm } \\
\hline & $\begin{array}{l}\text { Coeff. } \\
\text { (1) }\end{array}$ & $\begin{array}{l}\text { SE } \\
(2)\end{array}$ & $\begin{array}{l}\text { Coeff. } \\
(3)\end{array}$ & $\begin{array}{l}\text { SE } \\
(4)\end{array}$ & $\begin{array}{l}\text { Coeff. } \\
(5)\end{array}$ & $\begin{array}{l}\text { SE } \\
(6)\end{array}$ & $\begin{array}{l}\text { Coeff. } \\
(7)\end{array}$ & $\begin{array}{l}\text { SE } \\
(8)\end{array}$ \\
\hline \multicolumn{9}{|l|}{ Female } \\
\hline Treatment & -0.091 & {$[0.051]^{*}$} & -0.109 & {$[0.055]^{* *}$} & 0.002 & {$[0.053]$} & 4.316 & {$[1.517]^{* * *}$} \\
\hline Interaction & 0.015 & {$[0.064]$} & 0.086 & {$[0.063]$} & -0.012 & {$[0.068]$} & -3.112 & {$[1.938]$} \\
\hline Sum & -0.075 & {$[0.047]$} & -0.023 & {$[0.042]$} & -0.009 & {$[0.057]$} & 1.204 & {$[1.336]$} \\
\hline \multicolumn{9}{|l|}{ Aged 20-40 } \\
\hline Treatment & -0.084 & {$[0.044]^{*}$} & -0.079 & {$[0.052]$} & -0.052 & {$[0.056]$} & 3.284 & {$[1.436]^{* *}$} \\
\hline Interaction & 0.002 & {$[0.066]$} & 0.027 & {$[0.064]$} & 0.096 & {$[0.066]$} & -1.063 & {$[1.810]$} \\
\hline Sum & -0.082 & {$[0.054]$} & -0.051 & {$[0.047]$} & 0.045 & {$[0.053]$} & 2.221 & {$[1.335]^{*}$} \\
\hline \multicolumn{9}{|l|}{ Wealth } \\
\hline Treatment & -0.085 & {$[0.037]^{* *}$} & -0.067 & {$[0.037]^{*}$} & -0.006 & {$[0.043]$} & 2.622 & {$[1.023]^{* *}$} \\
\hline Interaction & 0.069 & {$[0.060]$} & 0.1 & {$[0.052]^{*}$} & 0.081 & {$[0.063]$} & 3.008 & [1.969] \\
\hline Sum & -0.015 & {$[0.075]$} & 0.032 & {$[0.063]$} & 0.075 & {$[0.075]$} & 5.63 & {$[2.387]^{* *}$} \\
\hline \multicolumn{9}{|c|}{ Muslim minority } \\
\hline Treatment & -0.089 & {$[0.040]^{* *}$} & -0.058 & {$[0.039]$} & -0.011 & {$[0.047]$} & 2.646 & {$[1.100]^{* *}$} \\
\hline Interaction & 0.054 & {$[0.097]$} & -0.054 & {$[0.091]$} & 0.061 & {$[0.104]$} & 0.97 & {$[3.335]$} \\
\hline Sum & -0.035 & {$[0.088]$} & -0.113 & {$[0.090]$} & 0.051 & {$[0.097]$} & 3.616 & {$[3.185]$} \\
\hline \multicolumn{9}{|c|}{ Any ethnic minority } \\
\hline Treatment & -0.087 & {$[0.040]^{* *}$} & -0.058 & {$[0.039]$} & -0.01 & {$[0.047]$} & 2.658 & {$[1.102]^{* *}$} \\
\hline Interaction & 0.039 & {$[0.098]$} & -0.06 & {$[0.091]$} & 0.054 & {$[0.104]$} & 0.822 & {$[3.344]$} \\
\hline Sum & -0.048 & {$[0.089]$} & -0.118 & {$[0.090]$} & 0.045 & {$[0.096]$} & 3.48 & {$[3.186]$} \\
\hline \multicolumn{9}{|c|}{ Prior peace education } \\
\hline Treatment & -0.116 & {$[0.090]$} & -0.136 & {$[0.075]^{*}$} & -0.016 & {$[0.103]$} & 1.329 & {$[2.188]$} \\
\hline Interaction & 0.08 & {$[0.210]$} & 0.18 & {$[0.163]$} & 0.033 & {$[0.218]$} & 3.612 & {$[5.137]$} \\
\hline Sum & -0.035 & {$[0.133]$} & 0.044 & {$[0.105]$} & 0.017 & {$[0.131]$} & 4.94 & {$[3.380]$} \\
\hline
\end{tabular}


We create an index for each thematic area, adding and standardizing questions so the index has zero mean and unit standard deviation. The indices are constructed such that more positive values indicate greater alignment with the messages of the training. Table A.5 displays all the questions in each index. 


\section{Table A.5: Questions on Attitudes, Norms and Skills}

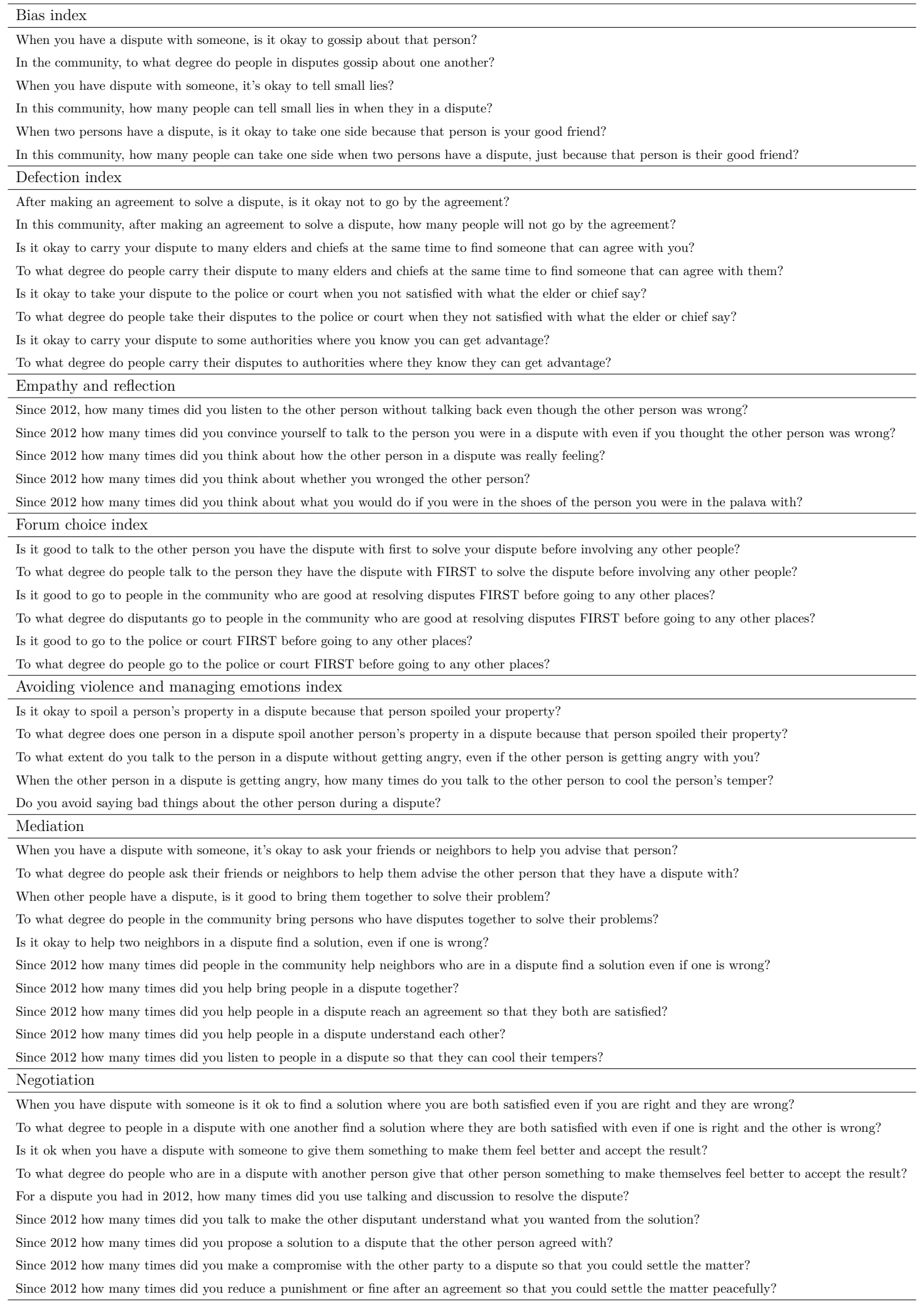

